\title{
AN ALIEN NAMED TIM
}

\section{The enemy within.}

\section{BY MICHAEL HAYNES}

\section{3:00 ship's time}

"Mwahahahaha!" The stowaway alien Tim, as he frequently reminded us - let out an evil laugh. An odd action, considering he was bound to a table with the ship's supply of nanorope.

I glanced at the captain, Bob. He glanced back at me. We both glanced at Tim.

"What?" Tim asked. "Is this not the victory laugh of the evil genius?"

"Yes," Bob said.

"Loosed when the evil genius has his enemies right where he wants them?"

"Quite," I said.

"Mwahahahaha!"

"Shouldn't that be our line?" Bob asked.

\section{0 minutes earlier}

The cargo-hold door was rattling. As this, generally, was not a good thing, Bob sent me to check it out.

We weren't armed; the trade routes had been peaceful for decades. The biggest risk to cargo haulers was catching something from one of the alien women at the waystations. A raygun wasn't much good against that sort of trouble.

I grabbed the longest screwdriver from the repair kit and went back towards the hold. Maybe there was just a screw loose.

I keyed in the door combination. It swung open and an alien sprang into the cabin.

"Freedom!" it yelled.

"What are you doing here?"

The alien shrugged. "I'm going to steal your ship, hijack your cargo, take it to my homeworld, and thereby use it to launch an invasion of your worlds."

"You're going to invade our worlds?"

"Uh-huh!"

"With processed soycheese and Antarean toe-fungus remover?"

The furry little thing just smiled at me.

"Seriously?"

"Have you ever mixed them together and let them ferment for one of your weeks?"

I hadn't. "Okay, fine. Let's say you could do that." I made a mental note to suggest to Interstellar that we not haul these products together again. "You said you were going to steal our ship. You and what army?"

"No army. Just Tim."

“Tim?"

The alien smiled again and pointed at himself.

"Everything okay back there?" Bob yelled.

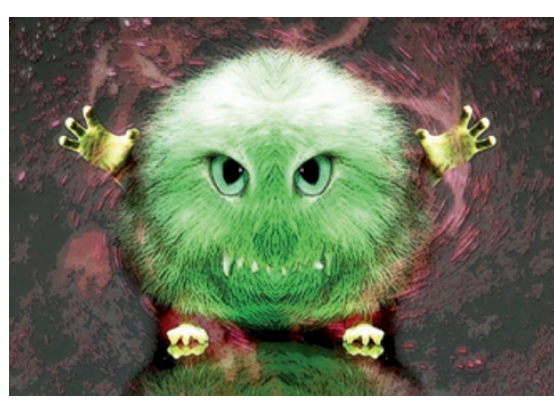

"Stowaway," I replied. Bob groaned. I knew why; he was thinking of all the paperwork.

"Is it a cute girl?" Bob asked.

"No. It's an ugly - "

"Hey!"

"- little alien. Green, furry. A bit smelly too."

"You try hanging out in a cargo bay with Antarean toe-fungus remover and tell me how you smell!"

"Fine," Bob said. "Throw it out the airlock."

I made a grab for Tim, who dodged my reach.

"I wouldn't advise this," Tim said.

"Why not?" I asked, lunging ineffectively.

"I've told you my intentions. That makes me an enemy combatant, so I'm entitled to a hearing by the Tribunal on Interspecies Conflict."

My third try at snagging Tim was a success.

"That's a good point," I said. "Except for one thing." I marched him towards the airlock. "Who's going to tell anyone that you didn't get your hearing?"

Tim squirmed, making it hard to key in the airlock code.

"My superiors know," Tim said as the door slid open and I tossed him into the airlock.

"I'm sure they'll be anxious to talk about their failed attack."

I began to enter the digits to close the door and cycle the airlock.

"Wait!"

I held my finger over the last button. "Yes?"

Tim stood, head hung. "What if Tim gave you the method for creating the toxic chemical from soycheese and fungus remover?"

I hesitated. This was out of my usual bailiwick. I also didn't want to learn some time that millions had died from a soycheese-antifungal attack that I could've helped prevent. $\rightarrow$ NATURE.COM

Follow Futures: @NatureFutures f go.nature.com/mtoodm
"You'll give that to me?"

Tim shook his head. I reached for the number pad again. "I'll give it to your bosses," he yelled, "when we get to your destination."

I retrieved him from the airlock and he went without a fight. I wouldn't fight, either, if someone was taking me out of an airlock rather than stuffing me into one.

I explained the situation to Bob.

"What'll we do with him until we get to Tyrena?” Bob asked.

"You could put me in the hold," Tim said.

"With the raw materials?" Bob said. "I don't think so."

"You have nanorope?"

"Naturally," I said. We used it to stow anything that needed to be tied down. The builtin nanobots made it indestructible unless cut with the matching knife. Bob nodded and soon I had Tim bound to our dining table.

Everything was quiet for a few minutes until Tim started his evil laugh.

\section{3:15 ship's time}

"I think our friend has a screw loose," Bob muttered. Tim was still cackling from the table; if his plan was to annoy us to death, he had a good start.

I went to grab a snack. As I got halfway across the cabin, the ship shuddered, knocking me down. Alarms wailed.

"What the hell?" Bob growled.

"Mwahahahaha!"

I looked at Tim. He was sitting up, bits of nanorope strewn around him.

"Sorry. Tim lied. Sort of."

The ship lurched again and I could feel it accelerating.

"What are you talking about?" I asked.

"Tim said he had no army. It was true then. But not now."

I looked again at the bits of nanorope well, just bits of rope, now. The ship's engines whined, straining at the demand placed on them by the nanobots now under Tim's command. Bob stood beside me, fists clenched.

"Give us back control of our ship!"

Tim shook his head and laughed again. He brushed aside what was left of the rope and stood up.

"I would throw you out the airlock," he said, "but you're too big for me and way too big for my nano-minions. But my people will give you a warm welcome on our homeworld."

He strolled past us, sat in the captain's chair and grinned at the now-useless control panel.

"Mwahahahaha!" -

Michael Haynes is a database administrator, writer, reader, movie watcher and hockey fan. 